\title{
Long non-coding RNAs in Epstein-Barr virus-related cancer
}

\author{
Yitong Liu, Zhizhong Hu, Yang Zhang* ${ }^{*}$ and Chengkun Wang*
}

\begin{abstract}
Epstein Barr-virus (EBV) is related to several cancers. Long non-coding RNAs (IncRNAs) act by regulating target genes and are involved in tumourigenesis. However, the role of IncRNAs in EBV-associated cancers is rarely reported. Understanding the role and mechanism of IncRNAs in EBV-associated cancers may contribute to diagnosis, prognosis and clinical therapy in the future. EBV encodes not only miRNAs, but also BART IncRNAs during latency and the BHLF1 IncRNA during both the latent and lytic phases. These IncRNAs can be targeted regulate inflammation, invasion, and migration and thus tumourigenesis. The products of EBV also directly and indirectly regulate host IncRNAs, including LINC00312, NORAD CYTOR, SHNG8, SHNG5, MINCR, InCRNA-BC200, LINC00672, MALATI1, LINC00982, LINC02067, IGFBP7-AS1, LOC100505716, LOC100128494, NAG7 and RP4-794H19.1, to facilitate tumourigenesis using different mechanisms. Additionally, IncRNAs have been previously validated to interact with microRNAs (miRNAs), and IncRNAs and miRNAs mutually suppress each other. The EBV-miR-BART6-3p/LOC553103/STMN1 axis inhibits EBV-associated tumour cell proliferation. Additionally, H. pylori-EBV co-infection promotes inflammatory lesions and results in EMT. HPV-EBV co-infection inhibits the transition from latency to lytic replication. KSHV-EBV co-infection aggravates tumourigenesis in huNSG mice. COVID-19-EBV co-infection may activate the immune system to destroy a tumour, although this situation is rare and the mechanism requires further confirmation. Hopefully, this information will shed some light on tumour therapy strategies tumourigenesis. Additionally, this strategy benefits for infected patients by preventing latency to lytic replication. Understanding the role and expression of InRNAs in these two phases of EBV is critical to control the transition from latency to the lytic replication phase. This review presents differential expressed IncRNAs in EBV-associated cancers and provides resources to aid in developing superior strategies for clinical therapy.
\end{abstract}

Keywords: Epstein-Barr virus, Long non-coding RNAs (IncRNAs), EBV latent infection, EBV lytic infection, Tumourigenesis

\section{Introduction}

Epstein Barr virus (EBV), a gamma-herpesvirus, was first identified in a case of Burkitt lymphoma in 1964 in Africa [1]. Although patients are usually asymptomatic, EBV causes lifelong persistent infection in more than $90 \%$ of adults worldwide [2]. Once an infection occurs, it is never cleared, and EBV remains in a subset of B lymphocytes \footnotetext{
Republic of China

*Correspondence: yangyang@usc.edu.cn; charleswzy@gmail.com Hunan Province Key Laboratory of Tumor Cellular \& Molecular Pathology, Cancer Research Institute, Hengyang Medical School, University of South China, 28 West Changsheng Road, Hengyang 421001, Hunan, People's throughout the life of the host [3]. EBV is an oncovirus associated with lymphomas and epithelial cell cancers [4-6] and has two modes of replication: replication via infected $B$ cell proliferation and replication via lytic virion production [7]. Both modes play essential roles in facilitating tumourigenesis. Three distinct processes exist in latency: viral persistence; limited virus expression that alters cell growth and proliferation; and retained potential for reactivation to lytic replication [8]. Typically, the lytic replication phase destroys host cells and is more likely to lead to Hodgkin's lymphoma, and inhibition of the lytic replication phase may benefit affected patients 
[7]. According to when they are produced within the virus circle, virus genes can be divided into latent infection genes, immediate-early genes, early genes and late genes (Fig. 1). Latent infection genes include six EBV-encoded nuclear antigens (EBNA-1, -2, -LP [leader protein], -3A, $-3 B$, and $-3 C$ ), two latent membrane proteins (LMP-1 and -2), two small noncoding RNAs (EBER-1 and -2), Bam$\mathrm{HI}$ A rightward transcripts (BARTs) and Bam-HI $\mathrm{H}$ leftward reading frame (BHLF), which are produced during latent infection to stimulate host cell proliferation [7, 9]. Among them, EBNA-1 is necessary for episome replication and virus persistence, and its tyrosine 518 (Y518) forms DNA protein crosslinks and facilitates replication termination at the EBV origin of plasmid replication (OriP). EBNA-2 is required for B lymphocyte immortalization and upregulates the expression of LMP-1 and LMP-2. LMP-1 is also essential for B lymphocyte immortalization and induces multiple activation markers. Additionally, LMP-1 can prevent EBV-infected B cells from undergoing apoptosis [8]. Immediate-early genes are the first group of genes expressed after activation of the virus from the latent state and include BZLF1 and BRLF1, which are transcription factors necessary to transition EBV into the lytic phase of infection. The early genes

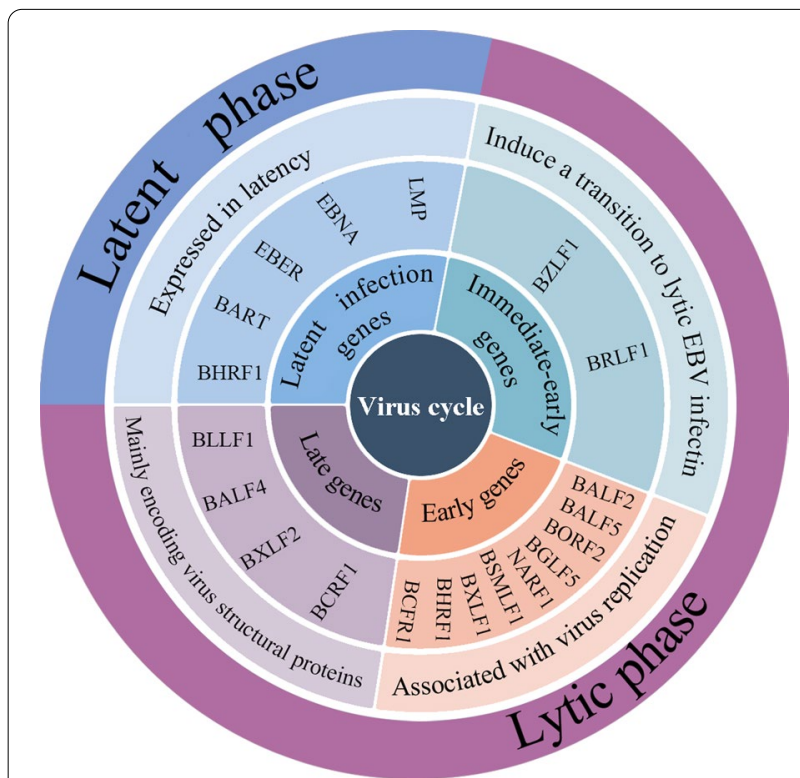

Fig. 1 Simplified summary of EBV-encoded genes during latent and lytic phases. Latent infection genes are encoded in the latent phase, such as LMP, EBNA, EBER, and BART. Immediate-early genes, including BZLF1 and BRLF1, encode proteins that promote the transition to EBV lytic infection. Early genes are associated with virus replication and include BALF2, BALF5, BORF2, BGLF5, NARF1, BSMLF1, BXLF1, BHRF1, and BCFR1. Late genes, including BLLF1, BALF4, BXLF2, and BCRF1, mainly encode virus structural proteins. Immediate-early genes, early genes, and late genes are expressed during the lytic phase include BALF5, BALF2, BORF2, NARF1, BGLF5, BXLF1, BHRF1, BMRF1 and BSMLF1, which are associated with virus replication. In addition, the late genes, mainly genes encoding viral structural proteins, are expressed after DNA replication, including BLLF1, BALF4, BXLF2 and BCRF1. Although the genome of EBV and its products have been studied in detail, the transition from latency to the lytic replication phase is remains unclear and the exact mechanism of the genes mentioned above in proliferation, immune escape, invasion and metastasis are not clearly defined tumourigenesis.

Long noncoding RNAs (lncRNAs), which are more than 200 nucleotides in length, were previously believed to be irrelevant in the genome and to not be transcribed [10]. Currently, IncRNAs are typically classified into four types: intergenic, intronic/intragenic, antisense and overlapping [11]. After genomic DNA transcripts to lncRNAs, some of them function in the nucleus, while others are transported to the cytoplasm, where lncRNAs can regulate mRNA stability, and translation and interfere with post-translational modifications in various manner [12]. LncRNA, as competitive endogenous RNA (ceRNA), compete with miRNA to stable mRNA and form double-stranded RNA (dsRNA) with mRNAs to stabilize mRNAs. However, LncRNAs can also act as RNA binding proteins (RBPs) involved in the degradation of mRNA [13]. Recently, lncRNAs were shown to play a regulatory role in gene expression and impact tumourigenesis [14-16]. What's more, lncRNAs have modest sequence conservation and are highly tissue-specific [17, 18], foreshadowing future diagnosis, prognosis and clinical therapy.

Previous studied have focused on miRNA in regulation of EBV and host cells, however, the wide distribution of lncRNAs in subcellular indicated that lncRNA also played an essential role in various regulatory processes. However, it remains to be further understood which lncRNAs are differentially expressed in the latency and lytic replication phases, and what their exact mechanism and roles are in EBV-infected cells. Herein, we summarize the role of lncRNAs in EBV-associated cancer from the aspects of EBV-encoded lnRNAs during latent phase and lytic phase, the associations between lncRNAs and miRNAs in EBV infection, and pathogens co-infected with EBV. We hope to provide hints concerning the subsequent discovery of biomarkers and clinical diagnosis and clinical therapy.

\section{EBV-encoded IncRNAs in the latent phase BART IncRNAs}

In addition to the well-established EBNA, LMP, and EBER genes, EBV has been found to express several spliced RNA transcripts, including BARTs [19]. EBV 
BARTs consist of two groups non-coding RNAs. One group is microRNAs (miRNAs), which are produced from introns before splicing. The other group is a complex family of alternatively spliced polyadenylated RNAs. These groups contribute to the reprogramming of host cell gene expression [20, 21]. Marquitz et al. believed that the latter group contained functional lncRNAs and suggested that the abundant expression of these lncRNAs facilitates tumourigenesis without the expression of immunogenic proteins. Additionally, previous studies have indicated that some BARTs are mainly found in the nucleus of nasopharyngeal carcinoma (NPC) C666-1 cells and that some BARTs are not exported to the cytoplasm $[22,23]$. Similarly, Verhoeven et al. hypothesized that BART lncRNAs reside in the nucleus of EBV-infected cells [24]. In addition, the most significant characteristic of EBV latency in NPC is high expression of BARTs, including lncRNAs and miRNAs, as there are few other EBV-derived products present during the latent phase [25]. It is reasonable that the expression of BARTs may be related to the oncogenic state in NPC.

Verhoeven et al. indicated that BART lncRNA-induced dysregulation of the expression of genes may result in promotion of cancer progression and metastasis and evasion of the immune response in NPC [24]. Aiolos, encoded by the IKZF3 gene, a lymphoid-restricted transcription factor, interacts with lkaros to modulate lymphocyte differentiation and usually not expressed in epithelial cells [26]; however, Aiolos is only expressed in EBV-positive NPC C666-1, the expression of IKZF3 is positively correlated with that of BART IncRNA isoform RPMS1, a size of approximately $4 \mathrm{~kb}$ and the most abundant BART transcript species in NPC [24]. In addition, inhibition of BART lncRNAs by GapmeRs results in downregulation of IKZF3 expression, followed by upregulation of p66Shc mRNA expression, but the protein level does not increase [24]. Several studies have demonstrated that the Src homology/collagen (Shc) adaptor protein plays a key role in apoptosis and the cellular redox state [27, 28]. In NPC C666-1 cells, overexpression of BART lncRNAs was found to be negatively correlated with the expression of IL- 6 by induced by GapmeRs. Similarly, several interferon genes, including IFNL1, IFNL2, IFNA1 and IFNB1, were apparently upregulated, and the cytokine genes IL5, IL10 and CXCL8, various interferon-stimulated genes (ISGs; ISG20, OAS2, IFIT1 and IFIT2), and CXCR2, which is a chemokine-related gene, were also upregulated by knockdown of BART lncRNAs in C666-1 cells, most of the genes above are related to the inflammatory and immune response, suggesting that EBV BART lncRNAs might regulate a host immune response that promotes immune evasion. Notably, IFIH1, which encodes MDA5, a cytoplasmic sensor of viral nucleic acids in host antiviral responses, is negatively correlated with BART lncRNAs. Additionally, Verhoeven also confirmed that BART lncRNA significantly inhibits mitochondrial antiviral signalling (MAVS)-induced IFN- $\beta$ promoter activity [24]. These results further confirm that BART lncRNAs play an immunomodulatory role. However, how do BART lncRNAs regulate the host genes associated with innate immunity? Verhoeven et al. demonstrated that BART lncRNAs block the expression of Pol II to regulate IFNB1 and CXCL8 expression and modulate host gene expression through interaction with CREB-binding protein (CBP) in EBV-infected cells by using indirect immunofluorescence and RNA FISH. Additionally, the expression of BART lncRNAs inhibited MAVS protein-induced histone acetyltransferase (HAT) activity and maintained latent EBV infection by influencing histone acetylation and methylation processes. These findings further suggest that during the gene transcription process, BART lncRNAs are also key regulators of chromatin remodelling. Besides, EBV BART lncRNAs upregulate the well-established biomarker Septin 9, which is hypermethylated in several cancers.

Likewise, Marquitz et al., using qRT-PCR, confirmed that BART lncRNAs downregulate several genes, including the tumour proapoptotic gene RNF144B; the secreted gastric protease-encoding gene PGC; the angiogenic factor-encoding gene VEGFA; ATF5 and SLC7A11, which are genes involved in cell adhesion and the unfolded protein response; and the migration-related genes RASIP1, 441 VEGFA, CDH11 and ITGA6, in six AGS-EBV cell lines [29]. Similarly, compared with an EBV-negative NPC cell line, the C666-1 cell line (which has high levels of BARTs) showed decreased expression of the ITGA6, CDN11, SLC7A11 and RASIP1 genes [29]. These results further suggest that the above genes share common functional mechanisms related to BART lncRNAs. The most widely recognized strategy by which lncRNAs silence genes is via the recruitment of Polycomb repressive complex 2 (PRC2) to remove the H3K27me3 marker [30]. Additionally, a prominent feature of EBV-positive gastric cancer (GC) is very high levels of CpG island promoter methylation, leading to the silencing of many important genes [31-33]. Marquitz et al. concluded that BART lncRNAs might contribute to the DNA methylation phenotype or influence histone regulation [29].

Verhoeven et al. further confirmed a feedback loop among LMP1, BARTs, and NF-kB in NPC and showed that activated $\mathrm{NF}-\mathrm{KB}$ signals promoted EBV latent infection. The expression of BART IncRNAs and BART miRNAs was upregulated by LMP1 activated BART promoters through NF- $\mathrm{kB}$ signalling, and the p50 and p65 NF- $\mathrm{kB}$ subunits could bind to the BART promoters; however, high expression of BART miRNA (mainly 
miR-BART5-5p, and to a lesser extent by miR-BART3-3p and miR-BART7-3p, but not miR-BART13-3p or miRBART14-3p) downregulated the expression of LMP1, providing negative feedback [25]. Inhibition of NF- $\mathrm{kB}$ signalling actually leads to BART overexpression and lytic replication [25]. It is reasonable to speculate that this feedback loop plays a role in maintaining persistent latent infection and avoiding entry into the lytic phase. (Fig. 2).

\section{BHLF1 IncRNAs}

Previous studies have indicated that the BHLF1 gene encodes several circular and a large number of linear RNAs that play non-coding roles during virus replication $[34,35]$. However, Yetming et al. recently demonstrated that BHLF1 is also transcribed during latency and may function mainly instead via its transcript as a lncRNA to contribute to viral latency and $B$ cell immortalization [36]. However, the specific role of BHLF1 lncRNA in tumourigenesis is still not clear. In fact, BHLF1 is known as an early lytic cycle gene [37]. Park et al. showed that the GC-rich EBV BHLF1 lncRNA was always present in virus-induced nodular structures (VINORCs) using FISH, which mediate the processing of pre-mRNA and the output of mRNA during lytic infection and thus lead to viral host shutoff (VHS). BHLF1 lncRNA may not play a role in VINORC assembly, however, a series of twelve $125 \mathrm{bp}$ tandem repeat sequences within BHLF1 suggests that lncRNA may play scaffolding and structural roles in recruitment of RNA-binding proteins and splicing factors

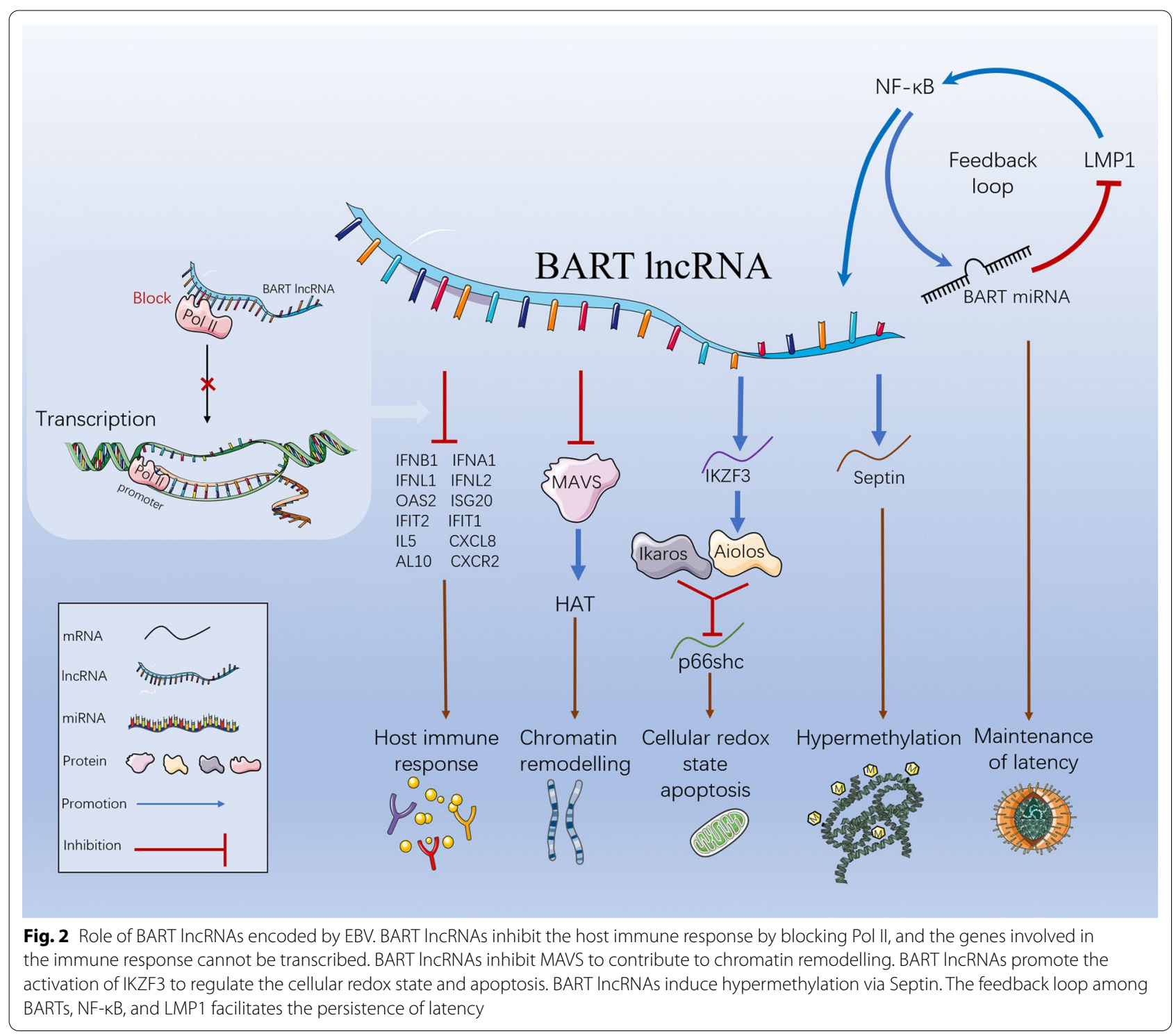


to VINORCs. Seven proteins (SC35, SON BMLF, Y14, SRp20, NXF1, ALY) are recruited to VINORCs and play roles in pre-mRNA splicing and mRNA nuclear export. However, the exact mechanism by which BHLF1 lncRNA recruits the above proteins requires further research [37].

\section{EBV-encoded IncRNAs in the lytic phase}

Latent infection is critical to the long-term survival of the host; in the latent phase, the virus does not replicate autonomously in the host, and its genome is replicated as the host cell replicates. Spreading of the virus from one cell to another and from one host to another requires lytic replication [38]. EBV lncRNAs might also act as key regulators of viral lytic replication and activate the expression of early and late genes by altering EBV chromatin structure [39]. Dresang et al. and O'Grady et al. indicated that more than a hundred novel lytic virus long non-coding RNAs are expressed by EBV [40, 41]. Cao et al. indicated that the origin of replication (oriP) in EBV latent infection is transcribed bidirectionally at the time of reactivation, with the leftward oriP (oriPtL) and the rightward oriP (oriPtR) mostly located in the nucleus, indicating that oriPtL-derived vlncRNAs promote the expression of lytic viral genes and contribute to the viral replication cascade. The transcripts of the oriPtL and oriPtR are viral late genes [38]. NONO is a multifunctional paraspeckle DNA binding protein that plays a role in transcriptional regulation $[42,43]$. Cao et al. found that NONO binds to oriP transcripts in the interaction between oriPts and the antiviral/stress response pathway, suggesting that these vlncRNAs are associated with paraspeckle-based innate antiviral immune pathways and contribute to the viral lytic cascade [38].

Similarly, O'Grady found that EBV lncRNAs binds to the viral genome in a heteroduplex manner and tags DNA for packing and concentrating for nuclear export of the newly synthesized viral genome [40]. Previous studies have mentioned that BHLF1 is found in VINORCs [37]. It is therefore reasonable to speculate that BHLF1 facilitates virus replication and spread.

Furthermore, lytic lncRNAs are potentially packaged in virions and might carry essential messages to promote the initial infection of epithelial cells or naïve B cells [38]. Gallo et al. found 9 lncRNAs (SNHG5, H19 antisense, H19 upstream conserved 1\&2, H19, 7SL, HOXA6as, NDM29, Tsix and HAR1B) in the cargo of the lymphoblastoid cell line (LCL) exosome cargo [44]. H19, one of the major cancer genes, is highly expressed in almost all cancers and participates in all phases of tumourigenesis $[45,46]$. 7SL expression is obviously upregulated in EBVinfected cells and repressed p53 translation in cancer cells. Moreover, the promoter sequences of 7SL resemble EBER genes [47-49]. These results indicated that
lncRNAs play a leading role in regulating of the tumour microenvironment. Besides, exosomes promote tumour immune escape and tumourigenesis [50, 51]. However, the mechanisms of exosome-related lncRNAs in immune escape is remain unclear. Hence, further exploration of the role of lncRNAs in exosomes in immune escape would be meaningful, and may provide new sights for clinical therapy.

\section{Host IncRNAs regulated by EBV}

Not only does the lncRNA encoded by EBV have an impact on the host, but EBV also regulates the expression of host lncRNAs, and this regulation has been confirmed to play both positive and negative roles in proliferation, invasion, immune escape and cell cycle (Figs. 3, 4).

Zhang et al. found that the expression of LINC00312, also termed as NAG7 and ERR-10 (represented by NAG7) [52], is downregulated in NPC, and NAG7 expression is positively associated with lymph node metastases and negatively related to clinical stage and tumour size. Moreover, the expression of NAG7 is indirectly downregulated by EBER-1, but the mechanism requires further study [53]. NAG7 can distinguish between non-cancerous and NPC patients, thus it may be a biomarker to diagnose and predict the clinical outcome of NPC.

NAG7 facilitates cell invasion by activating JUN pathways in NPC [54]. EBNA1 regulates the JUN transcription factor pathway in NPC and promotes angiogenesis in vitro [55]. Furthermore, the expression of JUN family members promotes cell proliferation in diffuse large B cell lymphomas [56]. The MAPK pathway, comprising c-Jun NH2-terminal kinase (JNK), ERK, and p38, is generally activated in human cancers, resulting in malignant phenotypes and is associated with metastatic behaviour in many cancer types [57-59]. NAG7 upregulates the expression of JNK2 and c-Jun and downregulates c-Fos, but ERK and p38 are not affected, leading to enhanced transcriptional activation of AP-1, followed by the transcription of MMP-1 [54]. MMP-1 may also affect the cytoskeletal arrangements considered to associate with different cell adhesion molecules (such as CD44 and integrins) to promote cell adhesion and motility [60]. Huang et al. shown that NAG7 overexpression increases the adhesion, invasion and motility of NPC HNE1 cells in vivo and in vitro via JNK2/AP-1/MMP1 [54]. Additionally, the Ras/Raf pathway is the upstream regulator that activates the MAPK signalling pathway in human cancers. Previous studies also suggested that NAG7 activates the $\mathrm{H}$-Ras/p-c-Raf pathway to promote tumourigeneses [54]. However, NAG7 prevents the cell cycle transition from $\mathrm{G} 1$ to $\mathrm{S}$ phase, inhibiting cell proliferation 


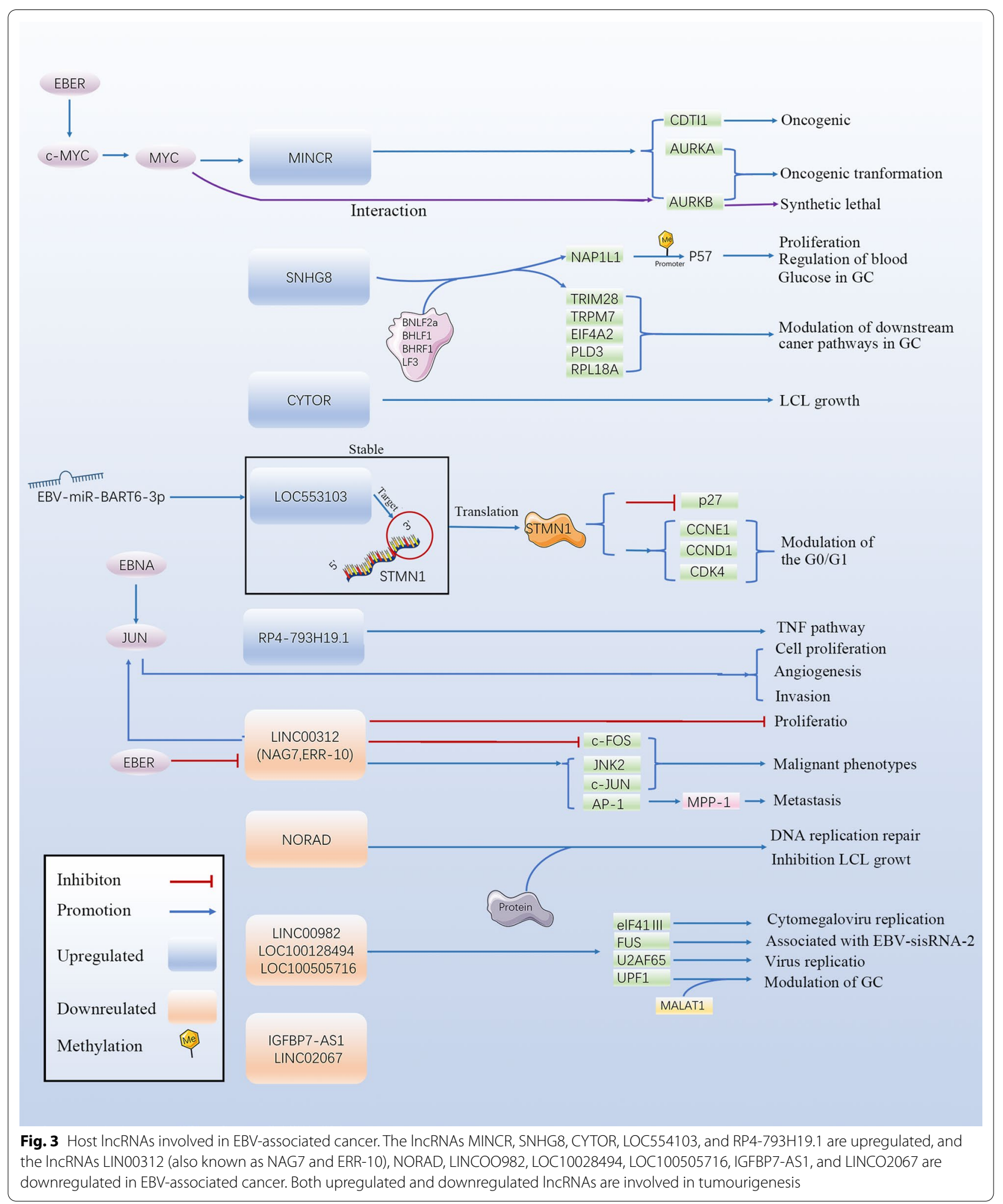




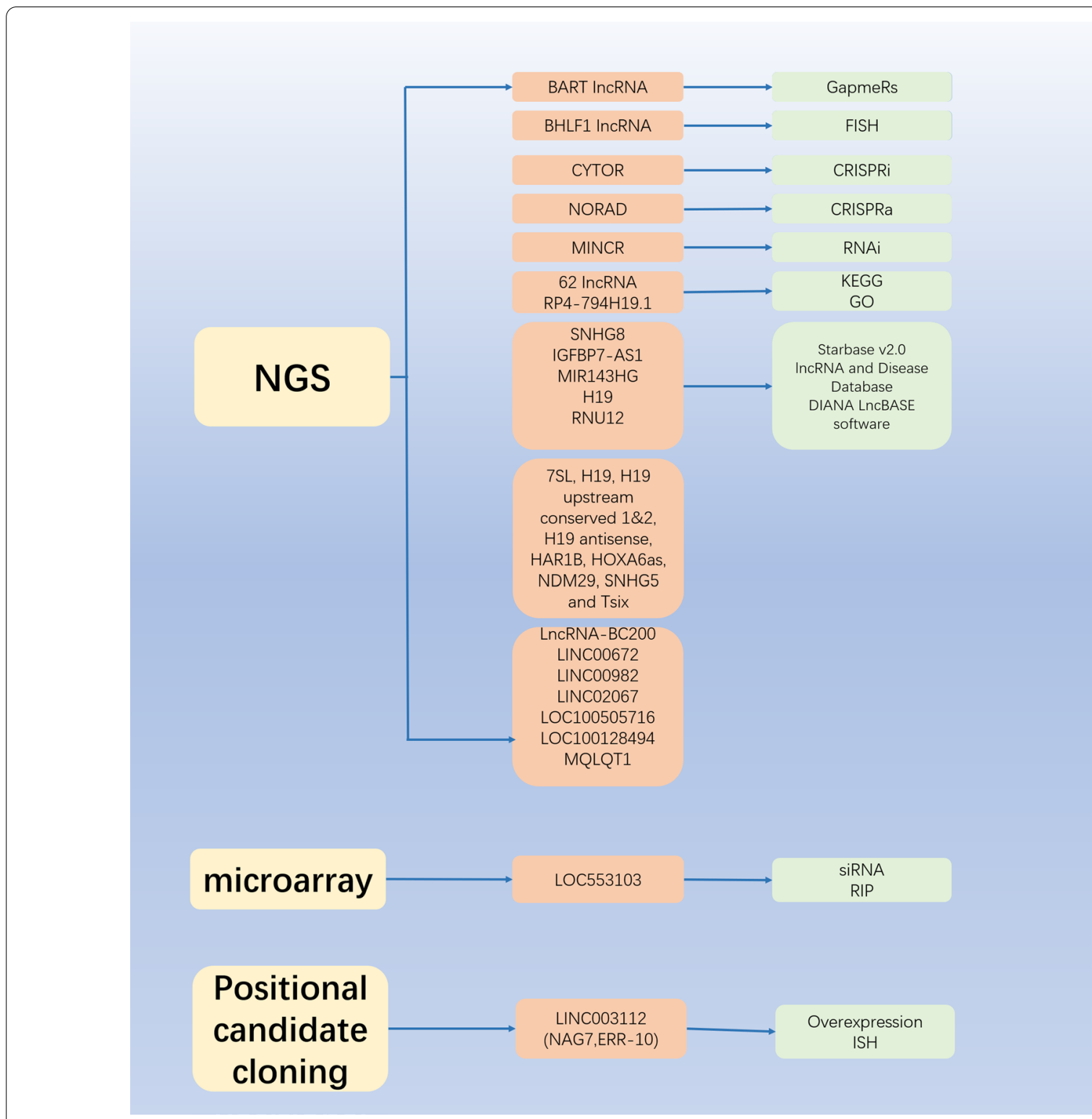

Fig. 4 Flowchart of the research methodology for each study. The differential expression of most InCRNAs was identified by NGS. LOC553103 was identified by microarray. LINC003112 was identified by positional candidate cloning. BART IncRNA was knocked down using the Gapmers technique for further study. BHLF1 IncRNA was identified by FISH. CYTOR was knocked down by CRISPRi, and NORAD was overexpressed by CRISPRa. MINCR was further evaluated using RNAi. Sixty-two InCRNAs and RP4-794H19.1 were predicted to be involved in their target pathways by KEGG and GO analyses. SNHG8, IGFB7-AS1, MIR143HG, H19, and RNU12 were predicted to be target genes using starBase v2.0, IncRNA and Disease Database and DIANA LnCBASE software. LOC553103 was further assessed using siRNA and RIP. LINC003112 was further studied using an overexpression plasmid and was identified in tissue samples for analysis relevant to ISH. NGS next-generation sequencing, FISH fluorescence in situ hybridization, RNAi RNA interference, CRISPRi CRISPR interference, CRISPRa CRISPR activation, RIP RNA-binding protein immunoprecipitation, ISH in situ hybridization

and inducing apoptosis in NPC [61-63]. Although the exact mechanism requires further study, NAG7 plays dual roles in the proliferation and invasion of NPC cells.

Additionally, Wang et al. identified lncRNAs in LCLs, including NORAD and CYTOR, which were differentially expressed during EBV infection by RNA-seq [64].
NORAD can bind to proteins that participate in DNA replication and repair [65]. What's more, the proteins PUMALIO1 and PUMILIO 2 bind to the PUMILIO response element (PRE) of the 8-nt sequence at the 3UTR of target mRNAs, subsequently activating mRNA deadenylation and decapping, and leading to accelerated 
turnover and decreased translation [66]. However, studies have shown that NORAD prefers to bind to PUM1/2 in the human cell cytoplasm because it contains 15-17 PREs and prevents the target mRNAs from degradation $[67,68]$. Lee et al. found that PUMILIO drives chromosomal instability by hyperactively repressing mitotic, DNA repair, and DNA replication factors in the absence of NORAD [69]. CYTOR is essential for breast cancer cell cytoskeleton maintenance, proliferation, and migration and is upregulated in multiple cancers [70, 71]. However, Wang et al. knocked down CYTOR with CRISPRi and upregulated NORAD with CRISPRa to significantly reduce LCL growth, suggesting that regulation of CYTOR and NORAD by EBV contributes to LCL survival and growth [64]. However, the exact mechanism between EBV and host lncRNAs needs to further study. In addition, further characterization of the role of the above lncRNAs would be interesting.

Huang et al. used deep sequencing to identify five EBVaGC-specific lncRNAs, RNU12, H19, SNHG8 and RP11-359D14.3, further identified the expression level by RT-PCR, H19, RNU12 and MIR143HG were identified as non-significant while RP11-359D143.3 was removed because of its unsatisfactory quality control results. Notably, lncRNA SNHG8 affected several GC-specific pathways by interacting with the EBV genes BHRF1, LF3, BHLF1 and BNLF2a and regulated the expression of TRPM7, TRIM28, EIF4A2, RPL18A, PLD3, and NAP1L1 [72]. The EBV genes BHLF1 and leftward reading frame 3 (LF3) were found in the polyribosome fraction of EBV-infected cells and were transcriptionally expressed in virus-associated tumours [73], both are associated with the lytic replication cycle, mainly in epithelial cells [74]. Furthermore, BHRF1 has 38\% sequence homology with the antiapoptotic protein $\mathrm{Bcl}-2$ and the function of BHLF is also similar to that of $\mathrm{Bcl}-2$, leading to persistent virus infection and contributing to tumourigenesis [75]. Additionally, BNLF2a, an early gene, may contribute to immune escape because its protein has two domains(a hydrophilic, cytosolic N-terminal domain and a hydrophobic, membrane-spanning $\mathrm{C}$-terminal domain) both of which are associated with the disruption of viral peptide transport into the endoplasmic reticulum and of peptide loading onto human leukocyte antigen class I molecules, leading to the reduction of endogenous antigen presentation and preventing recognition by CD8+ T-cells [76, 77]. TRIM28, TRPM7 and NAP1L1 influence downstream cancer pathways in GC. TRIM28 contributes to tumourigenesis and acts as an independent prognostic factor for poor survival in GC [78]. NAP1L1 regulates the methylation of the P57 (Kip2) promoter to influence the proliferation of pancreatic neuroendocrine tumour cells [79]. Moreover, Chen et al. proved that higher SNHG8 expression was associated with a later TNM stage in GC. Although no significant correlation was found between SNHG8 expression and tumour size, higher expression of SNHG8 was found in larger tumours, further demonstrating that SNGH8 promotes the development of tumours as a proto-oncogene [80]. The lncRNA SNHG5 is downregulated and correlated with TNM stage in GC [81]. Lin et al. confirmed that elevated fasting blood glucose levels and high levels of SNHG8 expression after radical gastrectomy predict a poor prognosis [82]. However, a recent study suggested that the lncRNA SNHG8 suppresses cell growth in EBV-associated GC [83]. These results reveal the regulation between IncRNAs and EBV in $\mathrm{GC}$ and provide a comprehensive understanding of the mechanism of immune escape, although the exact mechanism warrants further study. Additionally, the EBV-specific lncRNAs suggest that they may serve as predictive biomarkers.

MYC, a transcription factor, was first identified in Burkitt lymphoma (BL) but is expressed in all lymphomas (not only in BL) and affects the expression of several genes, leading to the development of many neoplasms [84-86]. Doose et al. identified a MYC-regulated lncRNA named MYC-induced long noncoding RNA (MINCR) that affects the expression of MYC-regulated cell cycle genes to control cell cycle processes. The expression levels of AURKA, AURKB and CDT1 are significantly affected by MINCR [87]. Furthermore, AURKA and AURKB have been shown to play essential roles in MYCinduced oncogenic transformation, and AURKB interacts with MYC, showing synthetic lethality [88]. A previous report suggested that CDT1 plays an oncogenic role in the progression of lymphoma [89]. What's more, Marquitz et al. also demonstrated that MYC was activated during EBV latent infection in AGS cells [29]. In type III latency, c-MYC is directly activated by EBNA2 [90]. However, as a modulator of the MYC transcriptional program, the mechanism by which MINCR regulates cell cycle progression in EBV-associated cancers must be further explored.

Zhang et al. identified eight lncRNAs in four EBVpositive cells with RNA-seq and qPCR analyses. LncRNA-BC200, LINC00672 and MALAT1 were significantly upregulated, while LINC00982, LINC02067, IGFBP7-AS1, LOC100505716, and LOC100128494 were expressed at low levels. In AGS cells (EBV-positive GC cells), IncRNA BC200, LINC00672, MALAT1 and LOC100128494 were significantly upregulated, while LINC02067 was downregulated. In C666-1 (EBVpositive NPC cells), lncRNA BC200, LINC00672 and LOC100128494 were upregulated while MALAT1 and LOC100505716 were downregulated. In addition, Zhang et al. demonstrated that the six lncRNAs other 
than IGFBP7-AS1 and LINC02067 (for which no data were available) target several common genes, including eIF4AIII, UPF1, FUS, and U2AF65, using egalovirus replication [91, 92] These results indicate that EBV may dysregulate host lncRNAs to regulate its own replication. Recent studies have reported that UPF1 regulates the development of GC by affecting the IncRNA MALAT1 [93]. Tompkins et al. predicted that FUS is associated with ebv stable intronic sequences (sisRNA2), a class of ncRNAs [94]. Moreover, Domsic et al. suggested that the general splicing factor U2AF65 modulates virus replication [95]. Furthermore, Kara et al. hypothesized that the IncRNA M3-04 is regulated by TMER8-derived antisense miRNAs and is relevant to reinforced lytic replication in vivo based on experiments in a murine model [96]. The above lncRNAs profile provides a resource to explore the mechanism of tumourigenesis between EBV and host lncRNAs.

Li et al. based on next-generation sequencing (NGS) analysis, suggested that 62 lncRNAs trans-regulated genes participate in the EBV infection pathway and that the proto-oncogene JUN was related to the cis-regulatory lncRNA RP4-794H19.1 and contributes to the tumour necrosis factor (TNF) signalling pathway in NPC, although these ideas need further practical validation [97]. Additionally, NGS, a high-throughput technique based on massive, small reads of the genome, enables rapid sequencing of the base pairs in DNA or RNA samples and the genomics data come from Whole Exome Sequencing (WES) and RNA sequencing (RNAseq). Kosvyra et al. suggested that utilizing the above data to create an integrated profile of a patient will allow better understanding of the disease and using chronic lymphocytic leukaemia (CLL) as an example to show that the profile efficiently summarizes the large-scale datasets including the results with the clinical profile and indicators from different data types [98]. Using NGS in patients with EBV-positive NPC, the previously described polymorphism in the promoter of the lytic transactivator of BZLF1 is associated with increased lytic replication $[99,100]$. The profile based on NGS facilitates medical research seeking differentially expressed genes and provides new possibilities for prognostic and precision medicine. These results suggest that products encoded by EBV profoundly affect host lncRNA regulation representing a potential biomarker for invasion, tumourigenesis and prognosis. Additionally, lncRNAs may be a potential target for clinical therapy and the treatment strategy must be further explored.

Agsalda-Garcia et al. proposed that a Raman-enhanced spectroscopy (RESpect) probe, which enhances Raman spectroscopy technology using portable fibreoptic devices, may identify potential markers for diagnosis by identifying the molecular chemical composition of tissues and cells [101]. Raman spectroscopy (RS) identifies chemical and molecular fingerprints of materials using inelastic scattering of photons with molecular bond vibrations, resulting in frequency energy shifts [102], therefore, RS has potential to identify differentiated tumour tissue. More importantly, the advantage of RESpect is its rapid, real-time assessment and noninvasiveness [103]. Agsalda-Garcia et al. discriminated childhood non-Hodgkin lymphomar (NHL) subtypes by standard RS instrumentation and the RESpect probe, confirming the feasibility of the RESpect probe [101]. RESpect, as a potential real-time screening instrument, can change the paradigm of screening for cancers. Additionally, RESpect provides the resource for researchers to explore novel molecules in tumours that may serve as biomarker for diagnosis or play a key role in regulating in tumourigensis.

\section{Associations between IncRNAs and RNAs in EBV infection}

LncRNAs have confirmed that interacting with RNAs (mRNAs or miRNAs) in various way plays a regulatory role in tumourigenesis [13]. LncRNA forms doublestranded RNA (dsRNA) with mRNA to regulate mRNA stability. Faghihi et al. found that beta-secretase-1 (BACE1) mRNA combines with BACE-1 antisense transcript (BACE1-AS) to contribute to BACE1 mRNA stability, leading to increased BACE1 protein expression in Alzheimer's disease [104]. By contrast, Gong et al. suggested that lncRNA half-STAU1-binding site RNA(1/2sbsRNAs) forms dsRNA with mRNA and recruit STAU1 to bind to mRNA and degrade mRNA [105]. What's more, lncRNAs can compete with endogenous RNAs and inhibit each other, thus establishing a regulatory ceRNA network (lncRNAs-miRNAs-mRNAs) that modulates target mRNAs [106]. There is increasing evidence supporting the existence of interactions between lncRNAs and miRNAs or mRNAs in several cancers [107-109] while EBV-associated cancers are no exception.

An aberrant lncRNA-mRNA-miRNA ceRNA network is also present in EBV-associated cancer. He et al. hypothesized that EBV-miR-BART-6-3p downregulates lncRNA LOC553103 to inhibit epithelial-mesenchymal transition (EMT), cell invasion and migration in NPC [110]. Additionally, Wang et al. indicated that the EBVmiR-BART6-3p/LOC553103/STMN1 axis inhibits EBVassociated tumour cell proliferation by modulating the expression of cell cycle-associated proteins. LOC553103 can directly target the 3'UTR of STMN1 mRNA, thereby stabilizing its structure and facilitating STMN1 translation. Knockdown of L0C553103 or STMIN1 can upregulate p27 and decrease CCNE1, CCND1, and CDK4, 
which are proteins involved in the G0/G1 cell cycle checkpoint [111]. These findings provide new insights into novel targeted therapies.

In addition, using miRwalk datasets, Jing et al. identified that both CXCL10 and GDF5 were in the ceRNA network and that they can be regulated by miR-6877-3p and two previously unreported lncRNAs (TP73-AS1 and RP5-1039K5.19). Eck et al. indicated that CXCL10, a strong angiostatic factor, is related to tumour-infiltrating $\mathrm{T}$ cells in GC [112]. GDF5, a growth differentiation factor, has proved that participates in EMT in salivary gland pleomorphic adenoma [113] and regulates TGF $\beta$ dependent angiogenesis in breast carcinoma [114]. Additionally, TP73-AS1 and RP5-1039K5.19 were identified in the ceRNA regulation network and have been identified as candidate targets in in-depth study on EBVaGC [115]. Although the mechanism mentioned above remains unclear, recognizing the crosstalk between viral miRNAs and lncRNAs is beneficial and will provide a theoretical and practical basis to determine the effect of EBV infection on carcinogenesis.

Sethuraman et al. provided bioinformatics evidence that Kaposi's sarcoma herpesvirus (KSHV) and EBV
miRNAs interact with cellular lncRNAs in an RNAinduced silencing complex (RISC)-dependent manner and demonstrated that lncRNAs participate in non-canonical miRNA binding, in which they bind to the 3 ' end of both viral and cellular miRNAs, more frequently than mRNAs. What's more, Sethuraman et al. suggested that miRNA-lncRNA interactions occur in both the nucleus and cytoplasm, although the mechanism must be further proven experimentally [106]. Furthermore, lncRNAs can bind to miRNAs, whether they are cellular or viral miRNAs, inhibiting miRNA-targeted mRNAs [116]. This information provides a resource to explore the biological correlation between lncRNAs and RNAs, and provides additional evidence that EBV-encoded genes regulate host lncRNAs.

\section{EBV co-infectious agents}

Viral co-infection has received increased attention, and identifying new mechanisms may provide new insight into novel clinical therapies (Fig. 5).

Helicobacter pylori (H. pylori) is currently recognized as a carcinogen and has been found to be related to several diseases of the stomach $[117,118]$. Carrasco et al.

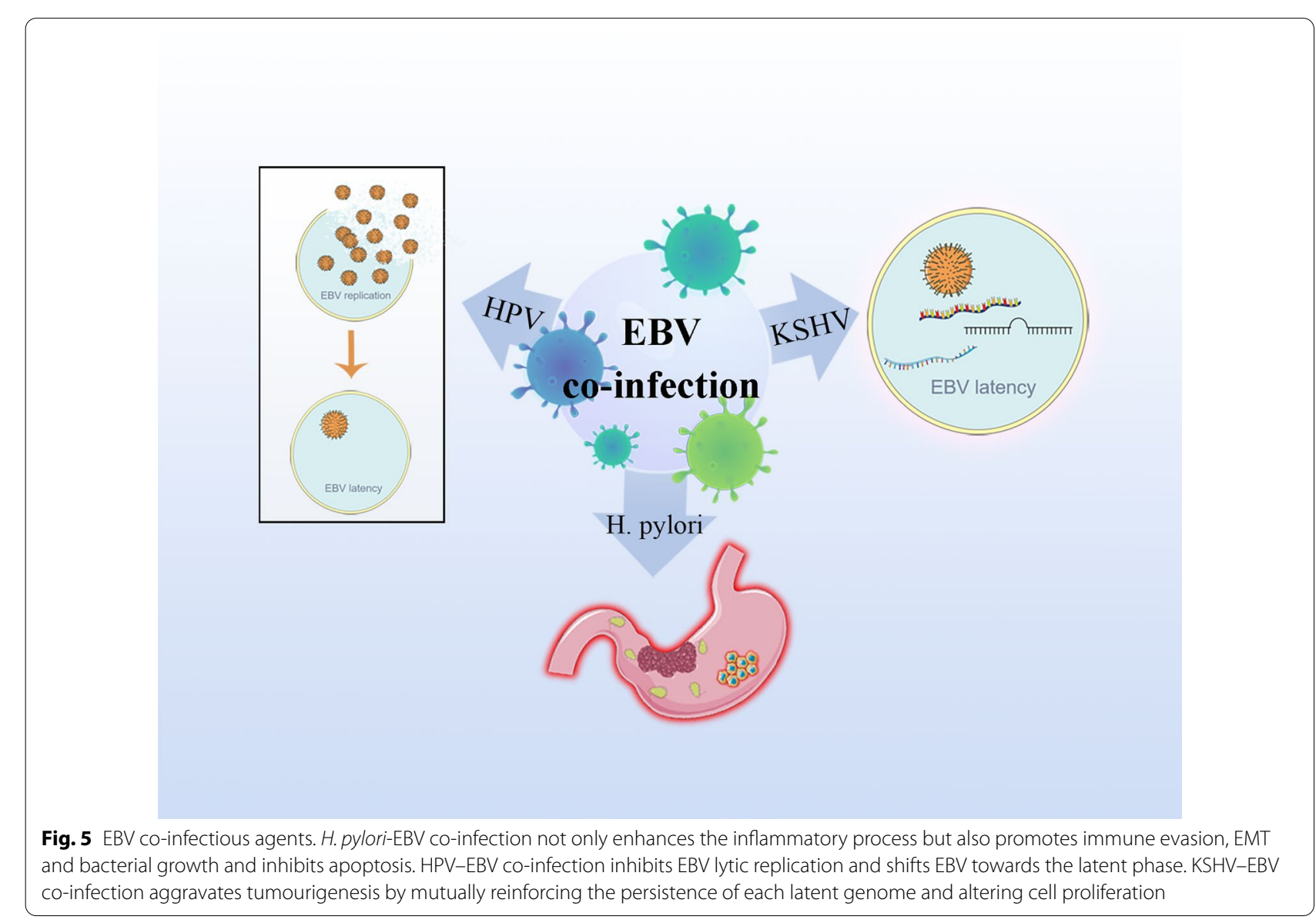


suggested that co-infection exacerbates inflammatory lesions compared with infection with only $H$. pylori or EBV [119]. In addition, Cardenas-Mondragon et al. indicated that GC with co-infection with EBV and H. pylori was related to premalignant lesions and intestinal-type GC [120]. The two pathogens have developed mechanisms that restrain the host inflammatory response and promote chronic colonization of the stomach, and infections in this area subsequently develop into chronic gastritis via induction of inflammation and lead to carcinogenic modifications. Yang et al. pointed out that CagApositive $H$. pylori strains promote cell proliferation and migration by inducing the expression of NF- $\mathrm{kB}$, which binds to the promoter of miR-223 to target ARID1A [121]. Previous studies have reported that NF- $k B$ also upregulates BARTs, including BART lncRNAs and BART miRNAs [25]. The relationship between these factors needs to be further explored. In addition, Liu et al. found that 23 lncRNAs were upregulated and 21 were downregulated in GES-1 cells infected with $H$. pylori. In particular, the lncRNAs XLOC_000620, XLOC_005912 and XLOC_004562 were apparently upregulated; however, XLOC_014388 and XLOC_004122 were expressed at low levels [122]. Furthermore, the let-7 and miR-200 families were downregulated by EBV and $H$. pylori coinfection, which led to enhanced inflammation and resulted in EMT. EBV and H. pylori also upregulate miR155 , thereby inhibiting the release of proinflammatory cytokines. H. pylori infection causes aberrant expression of lncRNAs, while EBV encodes its own viral ncRNAs, including lncRNAs and miRNAs. However, how H. pylori and EBV lead to tumourigenesis remains unclear.

Human papillomavirus (HPV) has been found to be related to cancers of the anogenital tract [123]. However, Guidry et al. infected EBV directly into HPV16-immortalized tonsillar cells and concluded that HPV E6 and E7 interfere with EBV early protein EA-D expression, leading to inhibited EBV lytic replication and a possible transition to EBV latent infection [124]. Nawandar et al. indicated that KLF4, which is downstream of E7, activates the expression of the EBV immediate-early genes BZLF1 and BRLF1, promoting the transition from latency to lytic replication [125]. In addition, studies have shown that differentiated cells express KLF4, PRDM1 and cellular transcription factors that activate the expression of immediate-early genes as well as LMP1 to promote EBV replication [125-127].

KSHV has been found to be related to multicentric Castleman's disease (MCD), which is caused by B cell lymphoproliferative disorders [128]. Additionally, McHugh et al. demonstrated that KSHV increases EBVassociated tumourigenesis by activating of lytic EBV replication in huNSG mice [129]. Latent nuclear antigen
(LANA) of KSHV shows effects similar to EBNA1, leading to persistence of episomal KSHV DNA in proliferating cells. Moreover, Bigi et al. highlighted that the complex interaction between KSHV and EBV aggravates the progression of cancer by carefully maintaining each latent genome and modifying cell proliferation [130].

SARS-CoV-2 (COVID-19), a pathogenic singlestranded RNA human coronavirus, continues to spread all globally and seriously affects human health [131]. In general, human $\mathrm{CoV}$ would not cause a deadly disease. However, human lack pre-existing natural immunity for zoonotic origin of COVID-19. However, humans lack pre-existing natural immunity due to the zoonotic origin of COVID-19. Additionally, the recent emergence of mutant strains suggests that the virus has adapted in humans to survive. Mutations in non-structural proteins may enhance replication of the viral genome. Furthermore, mutations within accessory proteins contribute to evasion or regulate host innate immunity, causing persistent virus replication. Parvez et al. considered that further rigorous genetic and molecular studies would update treatment and preventive strategies for recently emerged variants [131]. Additionally, Challenor et al. reported a case in which an EBV-positive Hodgkin lymphoma patient was diagnosed with COVID-19 4 months later, palpable lymphadenopathy was reduced, and a PET/CT scan showed widespread resolution of the lymphadenopathy and reduced metabolic uptake throughout [132]. Challenor et al. hypothesized that COVID-19 infection triggered an anti-tumour immune response and assumed that the mechanisms for this included cross-reactivity of pathogen-specific $\mathrm{T}$ cells with tumour antigens and the activation of natural killer cells by inflammatory cytokines produced by infection [132]. Although the assumption must be further explored and validated, understanding the mechanism of the above relationship will be valuable to cancer treatment.

\section{Conclusion}

Although most individuals infected with EBV are asymptomatic, EBV can cause various cancers, including lymphoma, NPC and GC. Viral infection is a dynamic balancing process involving host immunity. Most studies have reported the effect of miRNAs on tumourigenesis, but studies of the effect of lncRNAs on tumourigenesis are rare. The presence of these lncRNAs determines their influence on the body and whether they have positive or negative effects; however, the mechanism of their action must be further explored.

Compared with previous studies limited to miRNAs and proteins encoded by EBV, we focused on the introduction of lncRNAs in EBV-infected cells. We showed that EBV produces not only miRNAs but also lncRNAs. 
Regarding BART transcripts, one group comprised miRNAs, and the other group comprised lncRNAs. BART lncRNAs affect multiple inflammatory cytokines and promote immune escape. BHLF1 lncRNA has been suggested to play an important role in virus replication and spread. Additionally, host lncRNAs are directly or indirectly regulated in EBV-infected cells and are involved in proliferation, invasion, metastasis, and immune escape, such as lncRNA NAG7, CYTOR, NORAD, SNHG8, MINCR, IncRNA-BC200, LINC00672, MALAT1, LOC100128494, IncRNA RP4-794H19.1, LOC553103, TP73-AS1 and RP5-1039K5.19. Furthermore, lncRNAs are characterized by modest sequence conservation, are highly tissue-specific and can be used as good biomarkers for diagnosis, prevention and even monitoring during treatment. We also discussed the lncRNAs-miRNAmRNA network, indicating that lncRNAs not only directly target mRNAs but also interact with miRNAs to indirectly regulate the expression of mRNAs.

We also discussed EBV co-infectious agents. H. pyloriEBV co-infection promotes inflammatory lesions and results in EMT. HPV-EBV co-infection inhibits the transition from latency to lytic replication. KSHV-EBV co-infection aggravates tumourigenesis in huNSG mice. COVID-19-EBV co-infection may activate the immune system to destroy the tumour, although this situation is rare, and the mechanism must be further confirmed. Hopefully, this information will shed some light on tumour therapy strategies.

RESpect detects molecular chemical fingerprints rapidly and non-invasively, providing a method to identify more differential lncRNAs. Additionally, utilizing this approach may play a significant role in diagnosis, screening cancer and monitoring during treatment.

Furthermore, prevent latency into lytic replication in infected patients is considered beneficial. Although most latently infected B cells do not undergo lytic replication, latency can transition to the lytic replication phase. Understanding the role and expression of lncRNAs in these two phases of EBV is critical to control the transition from latency to the lytic replication phase.

In summary, we present differential lncRNAs in EBVassociated cancers, providing resources and novel insights for future diagnosis, prognosis and clinical therapy.

\footnotetext{
Abbreviations

EBV: Epstein-Barr virus; IncRNA: Long non-coding RNA; EBNA: EBV-encoded nuclear antigens; LP: Leader protein; LMP: Latent membrane protein; EBER: EBV-encoded RNA; BARTs: Bam-HI A rightward transcripts; BHLF: Bam-HI H leftward reading frame; HGNC: HUGO Gene Nomenclature Committee; CSTs: Complementary strand transcripts; ORFs: Open reading frames; microRNA: MiRNA; Shc: Src homology/collagen; MAVS: Mitochondrial antiviral signalling protein; HAT: Histone acetyltransferase; VINORCs: Virus-induced nuclear
}

structure; Vhs: Viral host shutoff; vIncRNA: Virus long non-coding RNA; oriP: Origin of replication; oriPtLs: Origin of replication with leftward; oriPtRs: Origin of replication with rightward; NPC: Nasopharyngeal carcinoma; GC: Gastric cancer; EBVaGC: Epstein-Barr virus associated gastric cancer; LCL: Lymphocyte line; BL: Burkitt lymphoma; EMT: Epithelial-mesenchymal transition; dsRNA: Double-strain RNA; KSHV: Kaposi's sarcoma-associated herpesvirus; RISC: RNA-induced silencing complexes; ceRNA: Competing for endogenous RNA; RESpect: Raman-enhanced spectroscopy; NHL: Non-hodgkin lymphoma; RS: Raman spectroscopy; H. pylori: Helicobacter pylori; HPV: Human papillomavirus; MCDL: Multicentric Castleman's disease; LANA: KSHV's latent nuclear antigen; V-FLIP: Viral FLICE/caspase 8 inhibit protein; NGS: Next-generation sequencing.

\section{Acknowledgements}

This work was supported by the Youth Program of National Natural Science Foundation of China (No. 81500169), Hunan Provincial Groundbreaking Platform Open Fund of University of South China (grant No. 19K080), and The Student Resarch Learning and Innovative Experimental Project of University of South China (grant No. 20155760439 and X2019141).

\section{Authors' contributions}

$\mathrm{YL}$ and $\mathrm{ZH}$ contributed equally to this manuscript. YL is responsible for writing the article. $\mathrm{ZH}$ is responsible for picture modification and article format adjustment. $Y Z$ and $C W$ are responsible for the direction and core of the article. All authors read and approved the final manuscript.

\section{Funding}

This work was supported by the Youth Program of National Natural Science Foundation of China (No. 81500169).

Availability of data and materials

Not applicable.

\section{Declarations}

Ethics approval and consent to participate

Not applicable.

Competing interests

All the authors declare that they have no conflicts of interest.

Received: 7 March 2021 Accepted: 13 May 2021

Published online: 25 May 2021

\section{References}

1. Epstein MA, Achong BG, Barr YM. Virus particles in cultured lymphoblasts from Burkitt's lymphoma. Lancet. 1964;1(7335):702-3. https://doi. org/10.1016/s0140-6736(64)91524-7.

2. Sitki-Green DL, Edwards RH, Covington MM, Raab-Traub N. Biology of Epstein-Barr virus during infectious mononucleosis. J Infect Dis. 2004;189(3):483-92. https://doi.org/10.1086/380800.

3. Babcock GJ, Decker LL, Volk M, Thorley-Lawson DA. EBV persistence in memory B cells in vivo. Immunity. 1998;9(3):395-404. https://doi.org/10. 1016/s1074-7613(00)80622-6.

4. Hewitt LC, Inam IZ, Saito Y, Yoshikawa T, Quaas A, Hoelscher A, Bollschweiler E, Fazzi GE, Melotte V, Langley RE, et al. Epstein-Barr virus and mismatch repair deficiency status differ between oesophageal and gastric cancer: a large multi-centre study. Eur J Cancer. 2018;94:104-14. https://doi.org/10.1016/j.ejca.2018.02.014.

5. Xu M, Yao Y, Chen H, Zhang S, Cao S-M, Zhang Z, Luo B, Liu Z, Li Z, Xiang T, et al. Genome sequencing analysis identifies Epstein-Barr virus subtypes associated with high risk of nasopharyngeal carcinoma. Nat Genet. 2019;51(7):1131-6. https://doi.org/10.1038/s41588-019-0436-5.

6. Ambinder RF. EBV, an inhibited receptor kinase, and lymphoma. Blood. 2016;128(12):1542-3. https://doi.org/10.1182/blood-2016-08-724955.

7. Munz C. Latency and lytic replication in Epstein-Barr virus-associated oncogenesis. Nat Rev Microbiol. 2019;17(11):691-700. https://doi.org/ 10.1038/s41579-019-0249-7. 
8. Sullivan JL, Luzuriaga K, Hirsch MS, Edwards MS, McGovern BH. Virology of Epstein-Barr virus. In: Bond S, editor. UpToDate 2019. Accessed 8 July 2019.

9. Rogers RP, Woisetschlaeger M, Speck SH. Alternative splicing dictates translational start in Epstein-Barr virus transcripts. EMBO J. 1990;9(7):2273-7. https://doi.org/10.1002/j.1460-2075.1990.tb07398.x.

10. Kapranov P, Cheng J, Dike S, Nix DA, Duttagupta R, Willingham AT, Stadler PF, Hertel J, Hackermüller J, Hofacker IL, et al. RNA maps reveal new RNA classes and a possible function for pervasive transcription. Science. 2007;316(5830):1484-8. https://doi.org/10.1126/science.11383 41.

11. Kung JTY, Colognori D, Lee JT. Long noncoding RNAs: past, present, and future. Genetics. 2013;193(3):651-69. https://doi.org/10.1534/genetics. 112.146704.

12. Chen YG, Satpathy AT, Chang HY. Gene regulation in the immune system by long noncoding RNAs. Nat Immunol. 2017;18(9):962-72. https:// doi.org/10.1038/ni.3771

13. Fatica A, Bozzoni I. Long non-coding RNAs: new players in cell differentiation and development. Nat Rev Genet. 2014;15(1):7. https://doi.org/ 10.1038/nrg3606

14. Prensner JR, lyer MK, Balbin OA, Dhanasekaran SM, Cao Q, Brenner JC, Laxman B, Asangani IA, Grasso CS, Kominsky HD, et al. Transcriptome sequencing across a prostate cancer cohort identifies PCAT-1, an unannotated lincRNA implicated in disease progression. Nat Biotechnol. 2011;29(8):742-9. https://doi.org/10.1038/nbt.1914.

15. He W, Liang B, Wang C, Li S, Zhao Y, Huang Q, Liu Z, Yao Z, Wu Q, Liao W, et al. MSC-regulated IncRNA MACC1-AS1 promotes stemness and chemoresistance through fatty acid oxidation in gastric cancer. Oncogene. 2019;38(23):4637-54. https://doi.org/10.1038/s41388-019-0747-0.

16. Müller V, Oliveira-Ferrer L, Steinbach B, Pantel K, Schwarzenbach H. Interplay of IncRNA H19/miR-675 and IncRNA NEAT1/miR-204 in breast cancer. Mol Oncol. 2019;13(5):1137-49. https://doi.org/10.1002/18780261.12472 .

17. Derrien T, Johnson R, Bussotti G, Tanzer A, Djebali S, Tilgner H, Guernec G, Martin D, Merkel A, Knowles DG, et al. The GENCODE v7 catalog of human long noncoding RNAs: analysis of their gene structure, evolution, and expression. Genome Res. 2012;22(9):1775-89. https://doi.org/ 10.1101/gr.132159.111.

18. Cabili MN, Trapnell C, Goff L, Koziol M, Tazon-Vega B, Regev A, Rinn $J \mathrm{~J}$. Integrative annotation of human large intergenic noncoding RNAs reveals global properties and specific subclasses. Genes Dev. 2011:25(18):1915-27. https://doi.org/10.1101/gad.17446611.

19. Hitt MM, Allday MJ, Hara T, Karran L, Jones MD, Busson P, Tursz T, Ernberg I, Griffin BE. EBV gene expression in an NPC-related tumour. EMBO J. 1989;8(9):2639-51. https://doi.org/10.1002/j.1460-2075.1989.tb084 04.X.

20. Pfeffer S, Zavolan M, Grässer FA, Chien M, Russo JJ, Ju J, John B, Enright AJ, Marks D, Sander C, et al. Identification of virus-encoded microRNAs. Science. 2004;304(5671):734-6. https://doi.org/10.1126/science.10967 81.

21. Jang B-G, Jung EJ, Kim WH. Expression of BamHI-A rightward transcripts in Epstein-Barr virus-associated gastric cancers. Cancer Res Treat. 2011:43(4):250-4 https://doi.org/10.4143/crt2011.43.4.250.

22. Al-Mozaini M, Bodelon G, Karstegl CE, Jin B, Al-Ahdal M, Farrell PJ. Epstein-Barr virus BART gene expression. J Gen Virol. 2009;90(Pt 2):307-16. https://doi.org/10.1099/vir.0.006551-0.

23. Edwards RH, Marquitz AR, Raab-Traub N. Epstein-Barr virus BART microRNAs are produced from a large intron prior to splicing. J Virol. 2008:82(18):9094-106. https://doi.org/10.1128/JVI.00785-08.

24. Verhoeven RJA, Tong S, Mok BW, Liu J, He S, Zong J, Chen Y, Tsao SW, Lung $\mathrm{ML}$, Chen $\mathrm{H}$. Epstein-Barr virus BART long non-coding RNAs function as epigenetic modulators in nasopharyngeal carcinoma. Front Oncol. 2019;9:1120. https://doi.org/10.3389/fonc.2019.01120.

25. Verhoeven RJ, Tong S, Zhang G, Zong J, Chen Y, Jin DY, Chen MR, Pan J, Chen H. NF-kappaB signaling regulates expression of Epstein-Barr virus BART MicroRNAs and long noncoding RNAs in nasopharyngea carcinoma. JVirol. 2016;90(14):6475-88. https://doi.org/10.1128/JVI. 00613-16.

26. Morgan B, Sun L, Avitahl N, Andrikopoulos K, Ikeda T, Gonzales E, Wu P, Neben S, Georgopoulos K. Aiolos, a lymphoid restricted transcription factor that interacts with Ikaros to regulate lymphocyte differentiation. EMBO J. 1997;16(8):2004-13. https://doi.org/10.1093/emboj/16.8.2004.

27. Gertz M, Steegborn C. The Lifespan-regulator p66Shc in mitochondria: redox enzyme or redox sensor? Antioxid Redox Signal. 2010;13(9):141728. https://doi.org/10.1089/ars.2010.3147.

28. Bhat SS, Anand D, Khanday FA. p66Shc as a switch in bringing about contrasting responses in cell growth: implications on cell proliferation and apoptosis. Mol Cancer. 2015;14:76. https://doi.org/10.1186/ s12943-015-0354-9.

29. Marquitz AR, Mathur A, Edwards RH, Raab-Traub N. Host gene expression is regulated by two types of noncoding RNAs transcribed from the Epstein-Barr virus BamHI a rightward transcript region. J Virol. 2015;89(22):11256-68. https://doi.org/10.1128/JVI.01492-15.

30. Margueron R, Reinberg D. The Polycomb complex PRC2 and its mark in life. Nature. 2011;469(7330):343-9. https://doi.org/10.1038/natur e09784.

31. Comprehensive molecular characterization of gastric adenocarcinoma. Nature. 2014;513(7517):202-9. https://doi.org/10.1038/nature13480.

32. Vo QN, Geradts J, Gulley ML, Boudreau DA, Bravo JC, Schneider BG. Epstein-Barr virus in gastric adenocarcinomas: association with ethnicity and CDKN2A promoter methylation. J Clin Pathol. 2002;55(9):669-75.

33. Kang GH, Lee S, Kim WH, Lee HW, Kim JC, Rhyu M-G, Ro JY. Epsteinbarr virus-positive gastric carcinoma demonstrates frequent aberrant methylation of multiple genes and constitutes $\mathrm{CpG}$ island methylator phenotype-positive gastric carcinoma. Am J Pathol. 2002;160(3):78794. https://doi.org/10.1016/S0002-9440(10)64901-2.

34. Ungerleider N, Concha M, Lin Z, Roberts C, Wang X, Cao S, Baddoo M, Moss WN, Yu Y, Seddon M, et al. The Epstein Barr virus circRNAome. PLoS Pathog. 2018;14(8):e1007206. https://doi.org/10.1371/journal. ppat.1007206.

35. Toptan T, Abere B, Nalesnik MA, Swerdlow SH, Ranganathan S, Lee N, Shair KH, Moore PS, Chang Y. Circular DNA tumor viruses make circular RNAs. Proc Natl Acad Sci USA. 2018;115(37):E8737-45. https://doi.org/ 10.1073/pnas. 1811728115.

36. Yetming KD, Lupey-Green LN, Biryukov S, Hughes DJ, Marendy EM, Miranda JL, Sample JT. The BHLF1 locus of Epstein-Barr virus contributes to viral latency and B-cell immortalization. J Virol. 2020. https://doi.org/ 10.1128/JVI.01215-20.

37. Park R, Miller G. Epstein-Barr virus-induced nodules on viral replication compartments contain RNA processing proteins and a viral long noncoding RNA. J Virol. 2018. https://doi.org/10.1128/JVI.01254-18.

38. Cao S, Moss W, O'Grady T, Concha M, Strong MJ, Wang X, Yu Y, Baddoo M, Zhang K, Fewell C, et al. New noncoding lytic transcripts derived from the Epstein-Barr virus latency origin of replication, oriP, are hyperedited, bind the paraspeckle protein, NONO/p54nrb, and support viral lytic transcription. J Virol. 2015;89(14):7120-32. https://doi.org/10.1128/ JVI.00608-15.

39. Norseen J, Thomae A, Sridharan V, Aiyar A, Schepers A, Lieberman PM. RNA-dependent recruitment of the origin recognition complex. EMBO J. 2008;27(22):3024-35. https://doi.org/10.1038/emboj.2008.221.

40. O'Grady T, Cao S, Strong MJ, Concha M, Wang X, Splinter Bondurant S, Adams M, Baddoo M, Srivastav SK, Lin Z, et al. Global bidirectional transcription of the Epstein-Barr virus genome during reactivation. J Virol. 2014;88(3):1604-16. https://doi.org/10.1128/JVI.02989-13.

41. Dresang LR, Teuton JR, Feng H, Jacobs JM, Camp DG, Purvine SO, Gritsenko MA, Li Z, Smith RD, Sugden B, et al. Coupled transcriptome and proteome analysis of human lymphotropic tumor viruses: insights on the detection and discovery of viral genes. BMC Genomics. 2011;12:625. https://doi.org/10.1186/1471-2164-12-625.

42. Petti E, Buemi V, Zappone A, Schillaci O, Broccia PV, Dinami R, Matteoni S, Benetti R, Schoeftner S. SFPQ and NONO suppress RNA:DNA-hybridrelated telomere instability. Nat Commun. 2019;10(1):1001. https://doi. org/10.1038/s41467-019-08863-1.

43. Iino K, Mitobe Y, Ikeda K, Takayama K-I, Suzuki T, Kawabata H, Suzuki Y, Horie-Inoue K, Inoue S. RNA-binding protein NONO promotes breast cancer proliferation by post-transcriptional regulation of SKP2 and E2F8. Cancer Sci. 2020;111(1):148-59. https://doi.org/10.1111/cas. 14240.

44. Gallo A, Vella S, Miele M, Timoneri F, Di Bella M, Bosi S, Sciveres M, Conaldi PG. Global profiling of viral and cellular non-coding RNAs in Epstein-Barr virus-induced lymphoblastoid cell lines and released 
exosome cargos. Cancer Lett. 2017;388:334-43. https://doi.org/10. 1016/j.canlet.2016.12.003.

45. Matouk IJ, DeGroot N, Mezan S, Ayesh S, Abu-lail R, Hochberg A, Galun E. The H19 non-coding RNA is essential for human tumor growth. PLOS ONE. 2007;2(9):e845.

46. Raveh E, Matouk IJ, Gilon M, Hochberg A. The H19 Long non-coding RNA in cancer initiation, progression and metastasis-a proposed unifying theory. Mol Cancer. 2015;14:184. https://doi.org/10.1186/ s12943-015-0458-2.

47. Felton-Edkins ZA, Kondrashov A, Karali D, Fairley JA, Dawson CW, Arrand JR, Young LS, White RJ. Epstein-Barr virus induces cellular transcription factors to allow active expression of EBER genes by RNA polymerase III. J Biol Chem. 2006;281(45):33871-80. https://doi.org/ 10.1074/jbc.M600468200

48. Chen W, Böcker W, Brosius J, Tiedge H. Expression of neural BC200 RNA in human tumours. J Pathol. 1997;183(3):345-51. https://doi.org/ 10.1002/(SICI) 1096-9896(199711)183:3\%3c345::AID-PATH930\%3e3.0 $\mathrm{CO} ; 2-8$.

49. Abdelmohsen K, Panda AC, Kang M-J, Guo R, Kim J, Grammatikakis I, Yoon J-H, Dudekula DB, Noh JH, Yang X, et al. 7SL RNA represses p53 translation by competing with HuR. Nucleic Acids Res. 2014;42(15):10099-111. https://doi.org/10.1093/nar/gku686.

50. Iero M, Valenti R, Huber V, Filipazzi P, Parmiani G, Fais S, Rivoltini L. Tumour-released exosomes and their implications in cancer immunity. Cell Death Differ. 2008;15(1):80-8. https://doi.org/10.1038/sj.cdd. 4402237.

51. Zhang H-G, Grizzle WE. Exosomes: a novel pathway of local and distant intercellular communication that facilitates the growth and metastasis of neoplastic lesions. Am J Pathol. 2014;184(1):28-41. https://doi.org/10.1016/j.ajpath.2013.09.027.

52. Meng Q, Zhao Z, Yan M, Zhou L, Li J, Kitt C, Bin G, Fan S. ERR-10: a new repressor in transcriptional signaling activation of estrogen receptoralpha. FEBS Lett. 2004;576(1-2):190-200. https://doi.org/10.1016/j. febslet.2004.07.094.

53. Zhang W, Huang C, Gong Z, Zhao Y, Tang K, Li X, Fan S, Shi L, Li X, Zhang $\mathrm{P}$, et al. Expression of LINC00312, a long intergenic noncoding RNA, is negatively correlated with tumor size but positively correlated with lymph node metastasis in nasopharyngeal carcinoma. J Mol Histol. 2013;44(5):545-54. https://doi.org/10.1007/ s10735-013-9503-X.

54. Huang C, Wu M, Tang Y, Li X, Ouyang J, Xiao L, Li D, Li G. NAG7 promotes human nasopharyngeal carcinoma invasion through inhibition of estrogen receptor alpha and up-regulation of JNK2/AP-1/ MMP1 pathways. J Cell Physiol. 2009;221 (2):394-401. https://doi.org/ $10.1002 / j c p .21867$

55. O'Neil JD, Owen TJ, Wood VHJ, Date KL, Valentine R, Chukwuma MB, Arrand JR, Dawson CW, Young LS. Epstein-Barr virus-encoded EBNA modulates the AP-1 transcription factor pathway in nasopharyngeal carcinoma cells and enhances angiogenesis in vitro. J Gen Virol. 2008;89(Pt 11):2833-42. https://doi.org/10.1099/vir.0.2008/003392-0.

56. Papoudou-Bai A, Goussia A, Batistatou A, Stefanou D, Malamou-Mitsi $\checkmark$, Kanavaros P. The expression levels of JunB, JunD and p-c-Jun are positively correlated with tumor cell proliferation in diffuse large B-cell lymphomas. Leuk Lymphoma. 2016;57(1):143-50. https://doi. org/10.3109/10428194.2015.1034704.

57. Aguirre-Ghiso JA, Ossowski L, Rosenbaum SK. Green fluorescent protein tagging of extracellular signal-regulated kinase and p38 pathways reveals novel dynamics of pathway activation during primary and metastatic growth. Cancer Res. 2004;64(20):7336-45. https://doi.org/10.1158/0008-5472.CAN-04-0113.

58. Koochekpour S, Sartor O, Hiraiwa M, Lee T-J, Rayford W, Remmel N, Sandhoff K, Minokadeh A, Patten DY. Saposin C stimulates growth and invasion, activates p42/44 and SAPK/JNK signaling pathways of MAPK and upregulates UPA/UPAR expression in prostate cancer and stromal cells. Asian J Androl. 2005;7(2):147-58. https://doi.org/10. 1111/j.1745-7262.2005.00037.x.

59. Gee JM, Barroso AF, Ellis IO, Robertson JF, Nicholson RI. Biological and clinical associations of c-jun activation in human breast cancer. Int J Cancer. 2000;89(2):177-86. https://doi.org/10.1002/(sici)10970215(20000320)89:2\%3c177::aid-ijc13\%3e3.0.co;2-0.
60. Hofmann UB, Westphal JR, Van Muijen GN, Ruiter DJ. Matrix metalloproteinases in human melanoma. J Invest Dermatol. 2000;115(3):337-44. https://doi.org/10.1046/j.1523-1747.2000.00068.x.

61. Tan C, Li J, Wang J, Xiang Q, Zhang X, Dong L, Shen S, Liang S, Li G. Proteomic analysis of differential protein expression in human nasopharyngeal carcinoma cells induced by NAG7 transfection. Proteomics. 2002;2(3):306-12. https://doi.org/10.1002/1615-9861(200203)2:3\% 3c306::aid-prot306\%3e3.0.co;2-\#.

62. Tan C, Li J, Xie Y, Xiang Q, Wang J-R, Liang S-P, Li G-Y. Preliminary function study of NAG7 Using Two-dimensional Electrophoresis and Mass Spectrometry. Sheng wu hua xue yu sheng wu wu li xue bao Acta biochimica et biophysica Sinica. 2001;33(4):373-8.

63. Tan C, Peng C, Huang Y-C, Zhang Q-H, Tang K, Li X-L, Li G-Y. Effects of NPC-associated gene NAG7 on cell cycle and apoptosis in nasopharyngeal carcinoma cells. Ai zheng Aizheng Chin J Cancer. 2002;21(5):449-55.

64. Wang C, Li D, Zhang L, Jiang S, Liang J, Narita Y, Hou I, Zhong Q, Zheng $\mathrm{Z}$, Xiao $\mathrm{H}$, et al. RNA sequencing analyses of gene expression during Epstein-Barr virus infection of primary B lymphocytes. J Virol. 2019. https://doi.org/10.1128/JVI.00226-19.

65. Munschauer M, Nguyen CT, Sirokman K, Hartigan CR, Hogstrom L, Engreitz JM, Ulirsch JC, Fulco CP, Subramanian V, Chen J, et al. The NORAD IncRNA assembles a topoisomerase complex critical for genome stability. Nature. 2018;561(7721):132-6. https://doi.org/10. 1038/s41586-018-0453-z.

66. Kopp F, Mendell JT. Functional classification and experimental dissection of long noncoding RNAs. Cell. 2018;172(3):393-407. https://doi. org/10.1016/j.cell.2018.01.011.

67. Yao RW, Wang Y, Chen LL. Cellular functions of long noncoding RNAs. Nat Cell Biol. 2019;21(5):542-51. https://doi.org/10.1038/ s41556-019-0311-8.

68. Munschauer M, Nguyen CT, Sirokman K, Hartigan CR, Hogstrom L, Engreitz JM, Ulirsch JC, Fulco CP, Subramanian V, Chen J, et al. Publisher Correction: The NORAD IncRNA assembles a topoisomerase complex critical for genome stability. Nature. 2018;563(7733):E32. https://doi.org/ 10.1038/s41586-018-0584-2.

69. Tichon A, Gil N, Lubelsky Y, Havkin Solomon T, Lemze D, Itzkovitz S, Stern-Ginossar N, Ulitsky I. A conserved abundant cytoplasmic long noncoding RNA modulates repression by Pumilio proteins in human cells. Nat Commun. 2016;7:12209. https://doi.org/10.1038/ncomm s12209.

70. Van Grembergen O, Bizet M, de Bony EJ, Calonne E, Putmans P, Brohée S, Olsen C, Guo M, Bontempi G, Sotiriou C, et al. Portraying breast cancers with long noncoding RNAs. Sci Adv. 2016;2(9):e1600220. https:// doi.org/10.1126/sciadv. 1600220

71. Liang J, Wei X, Liu Z, Cao D, Tang Y, Zou Z, Zhou C, Lu Y. Long noncoding RNA CYTOR in cancer: a TCGA data review. Clin Chim Acta. 2018;483:227-33. https://doi.org/10.1016/j.cca.2018.05.010.

72. Huang T, Ji Y, Hu D, Chen B, Zhang H, Li C, Chen G, Luo X, Zheng XW, Lin X. SNHG8 is identified as a key regulator of Epstein-Barr virus (EBV)associated gastric cancer by an integrative analysis of IncRNA and mRNA expression. Oncotarget. 2016;7(49):80990-1002. https://doi.org/ 10.18632/oncotarget.13167.

73. Xue S-A, Jones MD, Lu Q-L, Middeldorp JM, Griffin BE. Genetic diversity: frameshift mechanisms alter coding of a gene (Epstein-Barr virus LF3 gene) that contains multiple 102-base-pair direct sequence repeats. Mol Cell Biol. 2003;23(6):2192-201. https://doi.org/10.1128/mcb.23.6. 2192-2201.2003.

74. Xue S-A, Griffin BE. Complexities associated with expression of EpsteinBarr virus (EBV) lytic origins of DNA replication. Nucleic Acids Res. 2007;35(10):3391-406. https://doi.org/10.1093/nar/gkm170.

75. Desbien AL, Kappler JW, Marrack P. The Epstein-Barr virus BCl-2 homolog, BHRF1, blocks apoptosis by binding to a limited amount of Bim. Proc Natl Acad Sci USA. 2009;106(14):5663-8. https://doi.org/10. 1073/pnas.0901036106.

76. Horst D, van Leeuwen D, Croft NP, Garstka MA, Hislop AD, Kremmer E, Rickinson AB, Wiertz EJ, Ressing ME. Specific targeting of the EBV lytic phase protein BNLF2a to the transporter associated with antigen processing results in impairment of HLA class I-restricted antigen presentation. J Immunol. 2009;182(4):2313-24. https://doi.org/10.4049/ jimmunol.0803218. 
77. Liu S, Wang X, Shu J, Zhao Z, Sun Z, Luo B. Sequence analysis of EBV immune evasion gene BNLF2a in EBV associated tumors and healthy individuals from nasopharyngeal carcinoma endemic and nonendemic regions of China. J Med Virol. 2015;87(11):1946-52. https://doi. org/10.1002/jmv.24254.

78. Fitzgerald S, Sheehan KM, O'Grady A, Kenny D, O'Kennedy R, Kay EW, Kijanka GS. Relationship between epithelial and stromal TRIM28 expression predicts survival in colorectal cancer patients. J Gastroenterol Hepatol. 2013;28(6):967-74. https://doi.org/10.1111/jgh.12157.

79. Schimmack S, Taylor A, Lawrence B, Alaimo D, Schmitz-Winnenthal H, Büchler MW, Modlin IM, Kidd M. A mechanistic role for the chromatin modulator, NAP1L1, in pancreatic neuroendocrine neoplasm proliferation and metastases. Epigenet Chromatin. 2014;7:15. https://doi.org/10. 1186/1756-8935-7-15.

80. Chen BZ, Lin XD, Chen G, Hu D, Zhu Q, Shi Y, Wang XJ, Jin SF, Wang HF, Zheng XW. Expression of long non-coding RNA SNHG8 in Epstein-Barr virus-related gastric cancer and clinical outcome. Zhonghua Bing Li Xue Za Zhi. 2017;46(2):84-7. https://doi.org/10.3760/cma.j.issn.05295807.2017.02.004

81. Zhao L, Guo H, Zhou B, Feng J, Li Y, Han T, Liu L, Li L, Zhang S, Liu Y, et al. Long non-coding RNA SNHG5 suppresses gastric cancer progression by trapping MTA2 in the cytosol. Oncogene. 2016;35(44):5770-80. https:// doi.org/10.1038/onc.2016.110.

82. Lin Y, Hu D, Zhou Q, Lin X, Lin J, Peng F. Correction: The fasting blood glucose and long non-coding RNA SNHG8 predict poor prognosis in patients with gastric carcinoma after radical gastrectomy. Aging (Albany NY). 2018;10(12):4294. https://doi.org/10.18632/aging.101755.

83. Liu J, Yang C, Gu Y, Li C, Zhang H, Zhang W, Wang X, Wu N, Zheng C. Knockdown of the IncRNA SNHG8 inhibits cell growth in Epstein-Barr virus-associated gastric carcinoma. Cell Mol Biol Lett. 2018;23:17. https://doi.org/10.1186/s11658-018-0070-8.

84. Zhang C, Xu B, Lu S, Zhao Y, Liu P. HN1 contributes to migration, invasion, and tumorigenesis of breast cancer by enhancing MYC activity. Mol Cancer. 2017;16(1):90. https://doi.org/10.1186/s12943-017-0656-1.

85. Kessler JD, Kahle KT, Sun T, Meerbrey KL, Schlabach MR, Schmitt EM, Skinner SO, Xu Q, Li MZ, Hartman ZC, et al. A SUMOylation-dependent transcriptional subprogram is required for Myc-driven tumorigenesis. Science. 2012;335(6066):348-53. https://doi.org/10.1126/science.12127 28.

86. Ma L, Young J, Prabhala H, Pan E, Mestdagh P, Muth D, Teruya-Feldstein J, Reinhardt F, Onder TT, Valastyan S, et al. miR-9, a MYC/MYCN-activated microRNA, regulates E-cadherin and cancer metastasis. Nat Cell Biol. 2010;12(3):247-56. https://doi.org/10.1038/ncb2024.

87. Doose G, Haake A, Bernhart SH, López C, Duggimpudi S, Wojciech F, Bergmann AK, Borkhardt A, Burkhardt B, Claviez A, et al. MINCR is a MYC-induced IncRNA able to modulate MYC's transcriptional network in Burkitt lymphoma cells. Proc Natl Acad Sci USA. 2015;112(38):E526170. https://doi.org/10.1073/pnas.1505753112.

88. Yang D, Liu H, Goga A, Kim S, Yuneva M, Bishop JM. Therapeutic potential of a synthetic lethal interaction between the MYC protooncogene and inhibition of aurora-B kinase. Proc Natl Acad Sci USA. 2010;107(31):13836-41. https://doi.org/10.1073/pnas.1008366107.

89. Seo J, Chung YS, Sharma GG, Moon E, Burack WR, Pandita TK, Choi K. Cdt1 transgenic mice develop lymphoblastic lymphoma in the absence of p53. Oncogene. 2005;24(55):8176-86. https://doi.org/10.1038/sj.onc. 1208881.

90. Qiu J, Cosmopoulos K, Pegtel M, Hopmans E, Murray P, Middeldorp J, Shapiro M, Thorley-Lawson DA. A novel persistence associated EBV miRNA expression profile is disrupted in neoplasia. PLoS Pathog. 2011;7(8):e1002193. https://doi.org/10.1371/journal.ppat.1002193.

91. Hosmillo M, Sweeney TR, Chaudhry Y, Leen E, Curry S, Goodfellow I, Cho $\mathrm{K}-\mathrm{O}$. The RNA helicase elF4A is required for sapovirus translation. J Virol. 2016;90(10):5200-4. https://doi.org/10.1128/JVI.03174-15.

92. Ziehr B, Lenarcic E, Cecil C, Moorman NJ. The elF4AIII RNA helicase is a critical determinant of human cytomegalovirus replication. Virology. 2016:489:194-201. https://doi.org/10.1016/j.virol.2015.12.009.

93. Li L, Geng Y, Feng R, Zhu Q, Miao B, Cao J, Fei S. The human RNA surveillance factor UPF1 modulates gastric cancer progression by targeting long non-coding RNA MALAT1. Cell Physiol Biochem. 2017;42(6):2194206. https://doi.org/10.1159/000479994.
94. Tompkins VS, Valverde DP, Moss WN. Human regulatory proteins associate with non-coding RNAs from the EBV IR1 region. BMC Res Notes. 2018;11(1):139. https://doi.org/10.1186/s13104-018-3250-8.

95. Domsic JK, Wang Y, Mayeda A, Krainer AR, Stoltzfus CM. Human immunodeficiency virus type 1 hnRNP A/B-dependent exonic splicing silencer ESSV antagonizes binding of U2AF65 to viral polypyrimidine tracts. Mol Cell Biol. 2003;23(23):8762-72. https://doi.org/10.1128/mcb. 23.23.8762-8772.2003.

96. Kara M, O'Grady T, Feldman ER, Feswick A, Wang Y, Flemington EK, Tibbetts SA. Gammaherpesvirus readthrough transcription generates a long non-coding RNA that is regulated by antisense miRNAs and correlates with enhanced lytic replication in vivo. Noncoding RNA. 2019;5(1):6. https://doi.org/10.3390/ncrna5010006.

97. Li XX, Liang XJ, Zhou LY, Liu RJ, Bi W, Zhang S, Li SS, Yang WH, Chen ZC, Yang XM, et al. Analysis of differential expressions of long non-coding RNAs in nasopharyngeal carcinoma using next-generation deep sequencing. J Cancer. 2018;9(11):1943-50. https://doi.org/10.7150/jca. 23481.

98. Kosvyra A, Maramis C, Chouvarda I. Developing an integrated genomic profile for cancer patients with the use of NGS data. Emerg Sci J. 2019;3(3):157-67. https://doi.org/10.28991/esj-2019-01178.

99. Tsai M-H, Raykova A, Klinke O, Bernhardt K, Gärtner K, Leung CS, Geletneky K, Sertel S, Münz C, Feederle R, et al. Spontaneous lytic replication and epitheliotropism define an Epstein-Barr virus strain found in carcinomas. Cell Rep. 2013;5(2):458-70. https://doi.org/10.1016/j.celrep. 2013.09.012.

100. Correia S, Bridges R, Wegner F, Venturini C, Palser A, Middeldorp JM, Cohen Jl, Lorenzetti MA, Bassano I, White RE, et al. Sequence variation of Epstein-Barr virus: viral types, geography, codon usage, and diseases. J Virol. 2018;92(22):e01132-18. https://doi.org/10.1128/JVI.01132-18.

101. Agsalda-Garcia M, Shieh T, Souza R, Kamada N, Loi N, Oda R, AcostaMaeda T, Choi SY, Lim E, Misra A, et al. Raman-Enhanced Spectroscopy (RESpect) probe for childhood non-hodgkin lymphoma. Sci Med J. 2020;2(1):1-7. https://doi.org/10.28991/SciMedJ-2020-0201-1.

102. Butler HJ, Ashton L, Bird B, Cinque G, Curtis K, Dorney J, EsmondeWhite K, Fullwood NJ, Gardner B, Martin-Hirsch PL, et al. Using Raman spectroscopy to characterize biological materials. Nat Protoc. 2016;11(4):664-87. https://doi.org/10.1038/nprot.2016.036.

103. Austin LA, Osseiran S, Evans CL. Raman technologies in cancer diagnostics. Analyst. 2016;141(2):476-503. https://doi.org/10.1039/c5an01786f.

104. Faghihi MA, Modarresi F, Khalil AM, Wood DE, Sahagan BG, Morgan TE, Finch CE, St Laurent G, Kenny PJ, Wahlestedt C. Expression of a noncoding RNA is elevated in Alzheimer's disease and drives rapid feed-forward regulation of beta-secretase. Nat Med. 2008;14(7):723-30. https://doi.org/10.1038/nm1784.

105. Gong C, Maquat LE. IncRNAs transactivate STAU1-mediated mRNA decay by duplexing with 3'UTRs via Alu elements. Nature. 2011;470(7333):284-8. https://doi.org/10.1038/nature09701.

106. Sethuraman S, Thomas M, Gay LA, Renne R. Computational analysis of ribonomics datasets identifies long non-coding RNA targets of gammaherpesviral miRNAs. Nucleic Acids Res. 2018;46(16):8574-89. https://doi. org/10.1093/nar/gky459.

107. Juan L, Wang G, Radovich M, Schneider BP, Clare SE, Wang Y, Liu Y. Potential roles of microRNAs in regulating long intergenic noncoding RNAs. BMC Med Genom. 2013;6(Suppl 1):S7. https://doi.org/10.1186/ 1755-8794-6-S1-S7.

108. Li FP, Lin DQ, Gao LY. LncRNA TUG1 promotes proliferation of vascular smooth muscle cell and atherosclerosis through regulating miRNA-21/ PTEN axis. Eur Rev Med Pharmacol Sci. 2018;22(21):7439-47. https://doi. org/10.26355/eurrev_201811_16284.

109. Huang $Y$. The novel regulatory role of IncRNA-miRNA-mRNA axis in cardiovascular diseases. J Cell Mol Med. 2018;22(12):5768-75. https:// doi.org/10.1111/jcmm.13866.

110. He B, Li W, Wu Y, Wei F, Gong Z, Bo H, Wang Y, Li X, Xiang B, Guo C, et al. Epstein-Barr virus-encoded miR-BART6-3p inhibits cancer cell metastasis and invasion by targeting long non-coding RNA LOC553103. Cell Death Dis. 2016;7(9):e2353. https://doi.org/10.1038/cddis.2016.253.

111. Wang D, Zeng Z, Zhang S, Xiong F, He B, Wu Y, Li W, Tang L, Wei F, Xiang $B$, et al. Epstein-Barr virus-encoded miR-BART6-3p inhibits cancer cell proliferation through the LOC553103-STMN1 axis. FASEB J. 2020;34(6):8012-27. https://doi.org/10.1096/f.202000039RR. 
112. Eck M, Schmausser B, Scheller K, Brändlein S, Müller-Hermelink HK Pleiotropic effects of CXC chemokines in gastric carcinoma: differences in CXCL8 and CXCL1 expression between diffuse and intestinal types of gastric carcinoma. Clin Exp Immunol. 2003;134(3):508-15. https://doi. org/10.1111/j.1365-2249.2003.02305.x

113. Enescu AS, Mărgăritescu CL, Crăițoiu MM, Enescu A, Crăițoiu Ş. The involvement of growth differentiation factor 5 (GDF5) and aggrecan in the epithelial-mesenchymal transition of salivary gland pleomorphic adenoma. Rom J Morphol Embryol. 2013:54(4):969-76.

114. Margheri F, Schiavone N, Papucci L, Magnelli L, Serratì S, Chillà A, Laurenzana A, Bianchini F, Calorini L, Torre E, et al. GDF5 regulates TGFßdependent angiogenesis in breast carcinoma MCF-7 cells: in vitro and in vivo control by anti-TGFß peptides. PLoS ONE. 2012;7(11):e50342. https://doi.org/10.1371/journal.pone.0050342.

115. Jing JJ, Wang ZY, Li H, Sun LP, Yuan Y. Key elements involved in EpsteinBarr virus-associated gastric cancer and their network regulation. Cancer Cell Int. 2018;18:146. https://doi.org/10.1186/s12935-018-0637-5.

116. Thomson DW, Dinger ME. Endogenous microRNA sponges: evidence and controversy. Nat Rev Genet. 2016;17(5):272-83. https://doi.org/10. 1038/nrg.2016.20

117. Jones KR, Whitmire JM, Merrell DS. A tale of two toxins: Helicobacter pylori CagA and VacA modulate host pathways that impact disease. Front Microbiol. 2010;1:115. https://doi.org/10.3389/fmicb.2010.00115.

118. Moss SF. The clinical evidence linking Helicobacter pylori to gastric cancer. Cell Mol Gastroenterol Hepatol. 2017;3(2):183-91. https://doi. org/10.1016/j.jcmgh.2016.12.001.

119. Carrasco G, Corvalan AH. Helicobacter pylori-induced chronic gastritis and assessing risks for gastric cancer. Gastroenterol Res Pract. 2013;2013:393015. https://doi.org/10.1155/2013/393015.

120. Cardenas-Mondragon MG, Torres J, Flores-Luna L, Camorlinga-Ponce M, Carreon-Talavera R, Gomez-Delgado A, Kasamatsu E, Fuentes-Panana EM. Case-control study of Epstein-Barr virus and Helicobacter pylori serology in Latin American patients with gastric disease. Br J Cancer. 2015;112(12):1866-73. https://doi.org/10.1038/bjc.2015.175.

121. Yang F, Xu Y, Liu C, Ma C, Zou S, Xu X, Jia J, Liu Z. NF-kB/miR-223-3p/ ARID1A axis is involved in Helicobacter pylori CagA-induced gastric carcinogenesis and progression. Cell Death Dis. 2018;9(1):12. https:// doi.org/10.1038/s41419-017-0020-9.

122. Yang L, Long Y, Li C, Cao L, Gan H, Huang K, Jia Y. Genome-wide analysis of long noncoding RNA profile in human gastric epithelial cell response to Helicobacter pylori. Jpn J Infect Dis. 2015;68(1):63-6. https://doi.org/ 10.7883/yoken.JID.2014.149.

123. Ramqvist T, Dalianis T. Oropharyngeal cancer epidemic and human papillomavirus. Emerg Infect Dis. 2010;16(11):1671-7. https://doi.org/ 10.3201/eid1611.100452.
124. Guidry JT, Myers JE, Bienkowska-Haba M, Songock WK, Ma X, Shi M, Nathan CO, Bodily JM, Sapp MJ, Scott RS. Inhibition of Epstein-Barr virus replication in human papillomavirus-immortalized keratinocytes. J Virol. 2019. https://doi.org/10.1128/JVI.01216-18.

125. Nawandar DM, Ohashi M, Djavadian R, Barlow E, Makielski K, Ali A, Lee D, Lambert PF, Johannsen E, Kenney SC. Differentiation-dependent LMP1 expression is required for efficient lytic Epstein-Barr virus reactivation in epithelial cells. J Virol. 2017;91(8):e02438-16. https://doi.org/10. 1128/JVI.02438-16.

126. Nawandar DM, Wang A, Makielski K, Lee D, Ma S, Barlow E, Reusch J, Jiang R, Wille CK, Greenspan D, et al. Differentiation-dependent KLF4 expression promotes lytic Epstein-Barr virus infection in epithelial cells. PLoS Pathog. 2015;11(10):e1005195. https://doi.org/10.1371/journal. ppat.1005195.

127. Reusch JA, Nawandar DM, Wright KL, Kenney SC, Mertz JE. Cellular differentiation regulator BLIMP1 induces Epstein-Barr virus lytic reactivation in epithelial and $B$ cells by activating transcription from both the R and Z promoters. JVirol. 2015;89(3):1731-43. https://doi.org/10.1128/ JVI.02781-14.

128. Cesarman E, Chang Y, Moore PS, Said JW, Knowles DM. Kaposi's sarcoma-associated herpesvirus-like DNA sequences in AIDS-related body-cavity-based lymphomas. N Engl J Med. 1995;332(18):1186-91. https://doi.org/10.1056/NEJM199505043321802.

129. McHugh D, Caduff N, Barros MHM, Rämer PC, Raykova A, Murer A, Landtwing V, Quast I, Styles CT, Spohn M, et al. Persistent KSHV infection increases EBV-associated tumor formation in vivo via enhanced EBV lytic gene expression. Cell Host Microbe. 2017;22(1):73.e7. https://doi. org/10.1016/j.chom.2017.06.009.

130. Bigi R, Landis JT, An H, Caro-Vegas C, Raab-Traub N, Dittmer DP. EpsteinBarr virus enhances genome maintenance of Kaposi sarcoma-associated herpesvirus. Proc Natl Acad Sci USA. 2018;115(48):E11379-87. https://doi.org/10.1073/pnas.1810128115.

131. Parvez MK, Niyazi S. The genomic and structural organization of SARSCoV-2: a mutational perspective. SciMed J. 2021;3(1):59-65. https://doi. org/10.28991/SciMedJ-2021-0301-8.

132. Challenor S, Tucker D. SARS-CoV-2-induced remission of Hodgkin lymphoma. Br J Haematol. 2021;192(3):415. https://doi.org/10.1111/bjh. 17116.

\section{Publisher's Note}

Springer Nature remains neutral with regard to jurisdictional claims in published maps and institutional affiliations.
Ready to submit your research? Choose BMC and benefit from:

- fast, convenient online submission

- thorough peer review by experienced researchers in your field

- rapid publication on acceptance

- support for research data, including large and complex data types

- gold Open Access which fosters wider collaboration and increased citations

- maximum visibility for your research: over 100M website views per year

At $B M C$, research is always in progress.

Learn more biomedcentral.com/submissions 